\title{
Correction: Appetite disinhibition rather than hunger explains genetic effects on adult BMI trajectory
}

Eric J. Brunner (D) Koutatsu Maruyama - Martin Shipley • Noriko Cable $\cdot$ Hiroyasu Iso $\cdot$ Ayako Hiyoshi • Daryth Stallone - Meena Kumari - Adam Tabak (D) A Archana Singh-Manoux (D) John Wilson • Claudia Langenberg • Nick Wareham • David Boniface · Aroon Hingorani $\cdot$ Mika Kivimäki (D) Clare Llewellyn (iD

Published online: 1 February 2021

(c) The Author(s) 2021. This article is published with open access

Correction to: International Journal of Obesity https://doi.org/10.1038/s41366-020-00735-9

The original version of this article unfortunately contained a mistake in the ESM. The original article has been corrected.

Open Access This article is licensed under a Creative Commons Attribution 4.0 International License, which permits use, sharing, adaptation, distribution and reproduction in any medium or format, as long as you give appropriate credit to the original author(s) and the source, provide a link to the Creative Commons license, and indicate if changes were made. The images or other third party material in this article are included in the article's Creative Commons license, unless indicated otherwise in a credit line to the material. If material is not included in the article's Creative Commons license and your intended use is not permitted by statutory regulation or exceeds the permitted use, you will need to obtain permission directly from the copyright holder. To view a copy of this license, visit http://creativecommons. org/licenses/by/4.0/. 